\title{
Behind the Sealed-up Doors: The New Urban Renewal Movement in Beijing
}

\author{
WEI ZHAO \\ University of Utah
}

Based on a case study in Beijing, China, this paper examines the ways in which architecture reflects the charged relationship among power, economy and social relations within a society. Starting in April 2017, the Beijing municipal government enacted a new, three-year urban renewal policy that aims to restore and improve the built environment of the 2,435 alleyways in the historic center of the city. The local implementation, however, has focused on sealing doors and windows that have led to homes and small businesses for decades. As a result, thousands of businesses that had been providing daily services to local residents closed down, forcing many people to move to other cities. Drawing on archival research and limited interviews, this paper examines the characteristics of the existing urban fabric of the historic center of Beijing and analyzes the social context and execution process of the urban renewal policy. This paper argues that the Beijing municipal government uses the architecture of the 99 percent as a tool not only to eliminate non-permanent residents by decimating their places to work and live, but also to control social activities and residents' relations through reconstructing place at the local level. As a result, by taking over the ownership of the architecture of the 99 percent, the Beijing municipal government aims to create a new image of the capital of China as defined by the new master plan, a plan which is not only ahistorical, but also promulgates the ideas of regularity, singularity and segregation.

\section{INTRODUCTION}

On April 1, 2017, the government of Beijing enacted a new urban renewal policy, which intends to restore and improve the built environment of the 2,435 alleyways in the historic center of the city in three years. ${ }^{1}$ Although this policy targets a set of broad issues, the local implementation has focused primarily on one practice, as summarized in four Chinese characters: kai-qiang-da-dong (brake-walls-open-holes). Specifically, doors and windows that were not in the original design of the buildings, though in use for decades to connect homes and small businesses, are sealed-up to restore the appearance of the historic city. This simple and crude approach to recreating a historic urban built environment has caused thousands of businesses that had been providing daily services to local residents to close down, forcing many people to move to other cities and homeowners to remodel their dwellings in order to access their homes through alternative means.
Taking the urban renewal policy as a case study, this paper probes the ways in which architecture reflects the charged relationship among power, economy and social relations within a society. In so doing, this paper first investigates the history and characteristics of the existing urban fabric in the historic center of Beijing, which largely consists of the everyday architecture of the 99 percent. It then analyzes the social context and execution process of the urban renewal policy. Lastly, through examining the embedded issues and underlying agenda of this policy, this paper argues that the Beijing municipal government uses the architecture of the 99 percent as a tool to control not only population mobility on a larger scale, but also social activities and relations at the local level. As a result, while ignoring the fact that the architecture of the 99 percent belongs to the most vulnerable social groups of the city-the non-permanent residents and the local civilians-the Beijing municipal government is recreating an image of the new capital of China, an image which promulgates the ideas of regularity, singularity and segregation.

\section{EXISTING URBAN FABRIC IN THE HISTORIC CENTER OF BEIJING}

The existing urban fabric in the historic center of Beijing is still largely based on the urban planning of the thirteenth century. Nine north-south and six east-west major streets divided the city into urban blocks, within which, east-west oriented hutongs (small alleyways) ran between two parallel north-south major streets. Most of these hutongs were about 15 to 30 feet wide and 1,500 and 3,000 feet long. The land between the hutongs, about 230 feet deep on average, were filled with large courtyard houses with a standard size of 57,000 square feet. ${ }^{2}$ With the population increase during the Ming Dynasty (1368-1644), the courtyard house evolved into a new form that has been preserved till the present day, with a typical courtyard house at about 7,000 square feet. ${ }^{3}$ Regardless of its size, the courtyard house was designed to house an extended family of multiple generations. Except for the main entrance connected to the hutong, the courtyard house was usually enclosed by brick exterior walls. As a result, hutongs were long and narrow spaces framed by continuous solid walls on both sides that were dotted by gates of various styles (Figure 1).

After the founding of the People's Republic of China in 1949, even though the urban fabric of the historic city remained largely intact until recent decades, the ways in which residential spaces were used changed drastically. First, the 


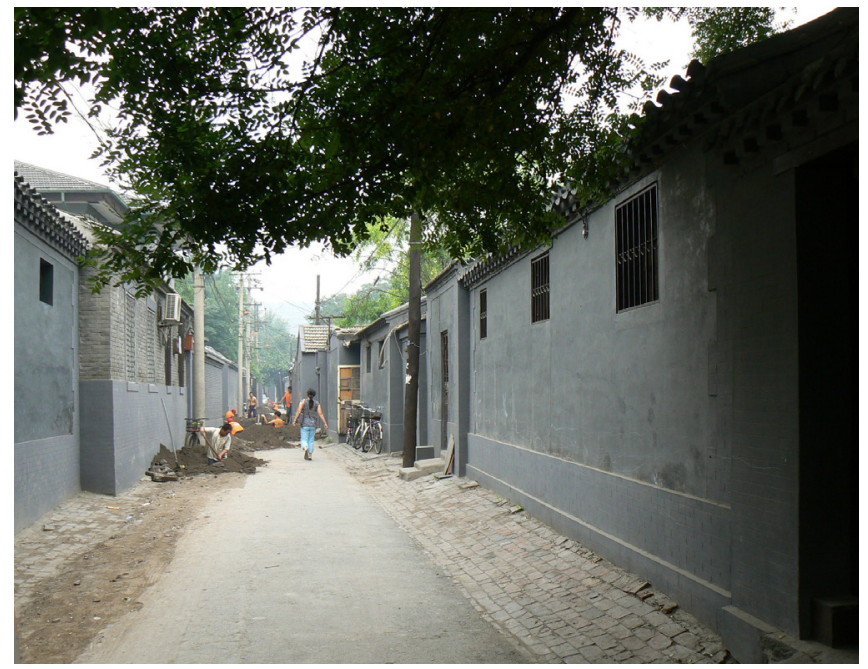

Figure 1: The view of a hutong. Photo by the author.

courtyard houses belonging to the imperial ruling class were confiscated and then remodeled to become homes for various kinds of institutions and their associated living quarters. In the late 1950s, many privately-owned courtyard houses were also appropriated by the government and turned into public housing to support the growing population of the city. As a result, many of these once private dwellings became communal houses, within which each family had only one or two rooms. ${ }^{4}$ Meanwhile, windows and doors were added to exterior walls of courtyard houses to support the communal living arrangement.

After the economic reform started in 1978, individuals were encouraged to run small businesses. Meanwhile, many young people returned to the city after the end of the Cultural Revolution seeking jobs. ${ }^{5}$ The first privately-owned business, a family-run restaurant, opened its doors inside a hutong in 1980. ${ }^{6}$ Many other businesses soon followed, which inevitably resulted in more openings along the once solid exterior walls of courtyard houses. Meanwhile, the central government first allowed (1984), then encouraged (1992) rural residents to migrate to urban areas to work and live. ${ }^{7}$ As a result, 37.2 percent of the people living in Beijing were migrants as of $2016 .{ }^{8}$ Based on a study conducted in 2014 focusing on the migrant population living in one of the historic districts of Beijing, 23.9 percent of these people were small business owners and 22.8 percent worked in service industries. Specifically, 49.2 percent of these migrants rented rooms inside courtyard houses and 20.9 percent lived and worked in the same space..$^{9}$ In addition, many local residents started running small businesses at home in the 1990s, when the transformation from a planned economy to a market economy caused many urban residents who worked at stateowned factories to lose their jobs. ${ }^{10}$

Inevitably, the increase of rental properties and small businesses inside the historic city center, while it did not alter the overall urban fabric, fundamentally changed the lives and dynamics in hutongs. The once continuous solid walls were broken down; they were activated and animated by convenience stores, small restaurants, coffee shops, hair salons, dry cleaners, and even dental clinics (Figure 2). Some of these businesses were too small to welcome customers into their space, but only used windows on the wall to handle the transactions. These businesses not only made lives in hutongs more convenient and lively, but also helped form an almost self-sustainable neighborhood where residents could take care of their daily needs within a short walking distance from home (Figure 3). In addition, the interactions between business owners and local customers, as well as among customers, helped build stronger social relations among residents, which were essential in creating a healthy and safe community. ${ }^{11}$

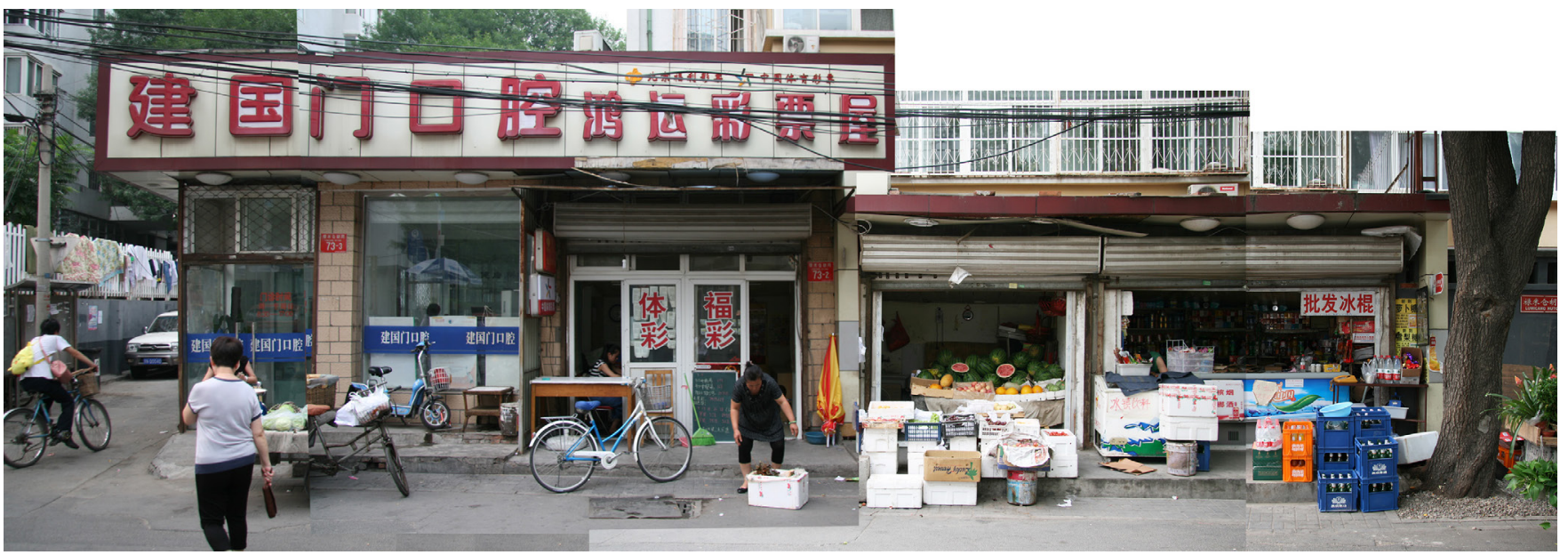

Figure 2: The once continuous solid wall inside Lvmicang Hutong has been broken down by continuous store fronts serving local residents. A collage of multiple photos taken by the author. 


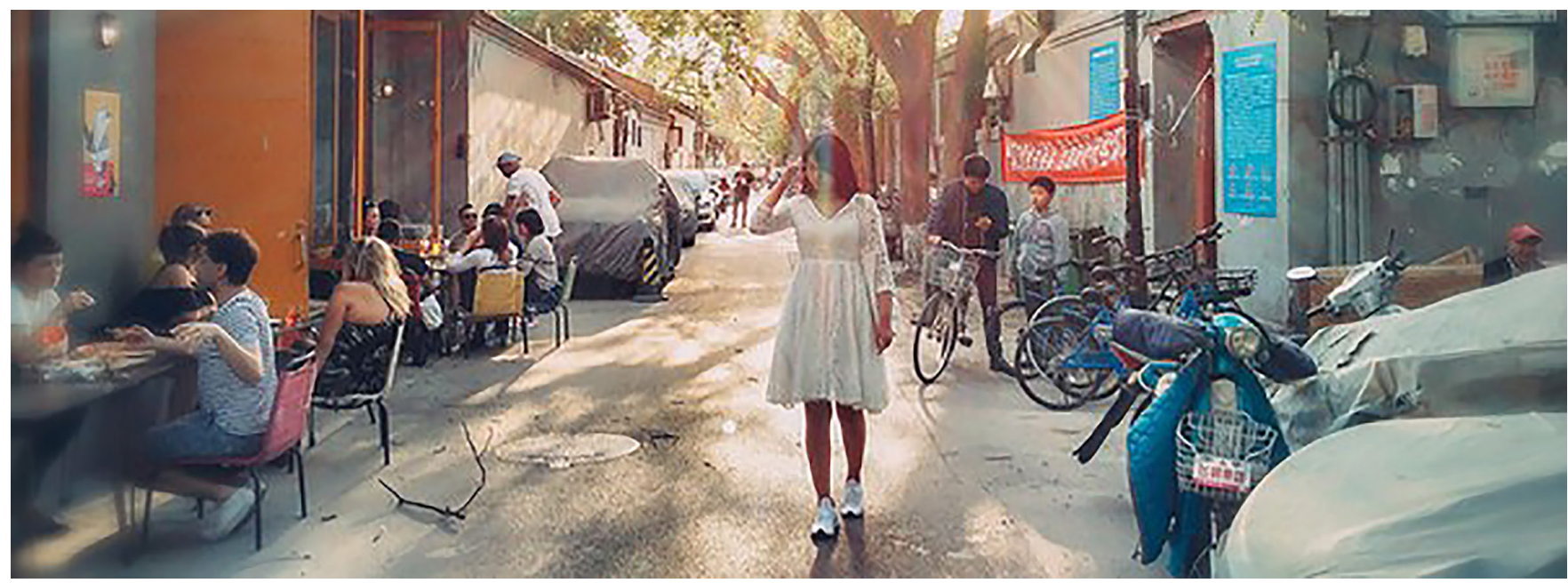

Figure 3: A lively street scene inside Fangjia Hutong before the renovation. Photo by Lvriguang (online ID), published on April 27, 2017 on http:// www.mafengwo.cn/i/6927923.html. Accessed on September 14, 2017.

\section{THE NEW URBAN RENEWAL MOVEMENT}

The new urban renewal plan emerged within a larger social context. On March 28, 2017, the Beijing municipal government announced the final draft of the "Beijing Master Plan 2016-2030" (hereafter the Master Plan). One of the key ideas is to relocate all the non-capital-related urban functions, such as state-owned companies, selected institutions, and certain service industries, in order to alleviate existing urban issues, such as population inflation, traffic, housing shortages, and pollution. In other words, the Master Plan is redefining the urbanscape, functionality and population of Beijing as a new capital of China. Meanwhile, the Master Plan calls for the preservation of the historic city. ${ }^{12}$ On April 1, 2017, the central government declared Xiong'an in Hebei Province the New District to receive the non-capital-related urban functions. ${ }^{13}$ On the same day, the Beijing municipal government released the urban renewal plan (hereafter the Plan), which aims to restore and improve the historic center of the capital city, as redefined in the Master Plan. ${ }^{14}$

Targeting the 2,435 backstreets and hutongs, the Plan calls for eliminating ten urban issues that not only focus on the appearance and infrastructure of the city, but also aim to reinforce planning and architectural regulations, such as eliminating illegal businesses, constructions, parking and billboards, as well as improving road conditions, public sanitation, urban green spaces, and building façades. However, from the perspectives of both the general public and the media, sealing doors and windows seems to be the only focus when the Plan is implemented at the local level. This general impression has resulted in a popular name for the Plan: brake-walls-open-holes.

This generally impression derives from two reasons. First, the local implementation of the Plan usually focuses only on selective issues included in the Plan. For example, in the public announcement posted by the Jianguomen Neighborhood Office in Lvmicang Hutong on April 20, the local government focused on four issues, which were eliminating illegal constructions, brake-walls-open-holes, billboards, and parking. ${ }^{15}$ Nevertheless, as had happened elsewhere in the city, sealing doors and windows became the main focus when the local government executed the Plan at Lvmicang Hutong on April 27. ${ }^{16}$ More importantly, eliminating illegal constructions, billboards and parking are changes that are generally welcomed by the general public, with little negative effect on local residents' lives. However, sealing doors and windows that lead to homes and small businesses can greatly affect the lives of home and business owners, as well as other local residents. In addition, with only a six-day advance notice, as was the case for residents of Lvmicang Hutong, it becomes next to impossible for home and business owners to find alternative places to continue their lives. Therefore, the impact of sealing doors and windows on such a large scale and at such a rapid pace is profound. In other neighborhoods, some home and business owners still attempted to continue their former lives, albeit in an alternative way, such as entering the space using a ladder through a window (Figure 4). Meanwhile, such images sweeping through social media further reinforce the general impression that the Plan is not, in fact, about city improvement, but rather about sealing doors and windows.

\section{BEHIND THE SEALED-UP DOORS AND WINDOWS}

One year before the release of the Plan, Prime Minister LI Keqiang expressed his concerns about similar master plans elsewhere in China. He said, "certain biases exist in some master plans and administrative approaches, which simply seek for 'ordered environment' at the cost of losing small businesses. These cities are essentially dead towns without vitality." ${ }^{17}$ Since the release of the Plan, this quote has been repeatedly cited by various sources. However, it has not yet influenced the local governments' approach to executing the Plan. 


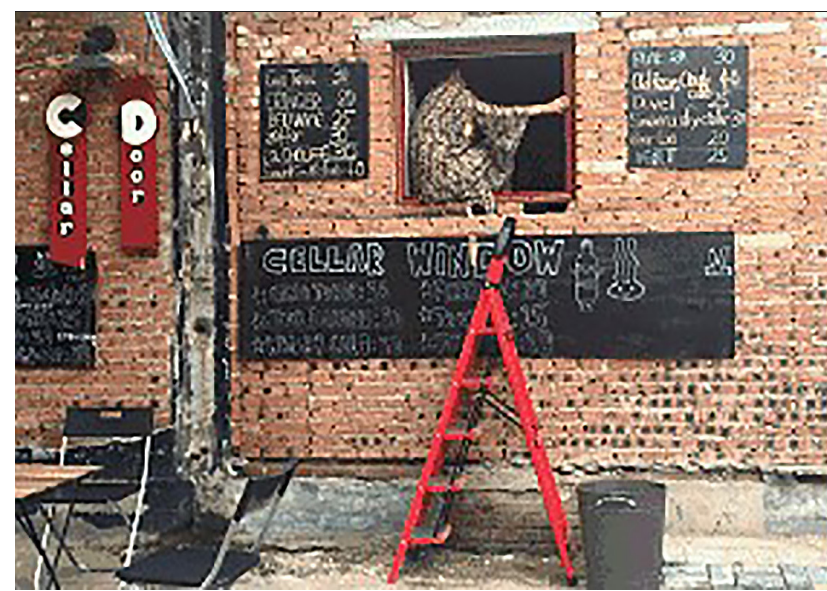

Figure 4: The owner of the bar at Fangjia Hutong No. 55 entering her store using a ladder through one of the two windows left on the exterior wall of the courtyard house. A few tables were set up outside the bar to serve customers. Photo by CHU Ge and LI Zi on July 17, 2017, published on https:// kknews.cc/travel/a8r9y3g.html. Accessed on September 16, 2017.

When examining such an urban renewal plan that not only has discrepancies between the written goals and the ways the plan is implemented, but also fails to receive support from either the prime minister or the general public, one must wonder: what are the real issues behind this urban renewal movement, and what are the underlying agendas behind the sealed-up doors and windows?

\section{EMBEDDED ISSUES}

The issues embedded in both the Plan and its local implementation are rooted in the two words that summarize its goal: improve and restore. First, what is the definition of improvement when examining the built environment? Although the Plan seem to focus on improving the physical appearance and infrastructure of the built environment, the implementation of the Plan has a more limited approach: to seal doors and windows. Comparing to store fronts carefully articulated by business owners in various styles, colors and materials, street elevations after the renovation are not only unrefined, but also often left unfinished (Figure 4, 5). Even after all the walls are painted in grey color months later, this paper, following Rowe and Koetter's assertion, argues that a unified façade is not an improvement from a collaged street edge because the latter not only assimilates both historic memories and present realities, but also creates a balance between tradition and innovation. ${ }^{18}$

Secondly, to restore hutongs to their historic appearance is to deny that the built environment is a living organism, which not only evolves in response to sociocultural changes, but also provides a dynamic framework to support social relations. In addition, by simply focusing on the physical appearance of the built environment, the Plan overlooks the importance of human factors in shaping the built environment. Ever since hutongs and courtyard houses were first

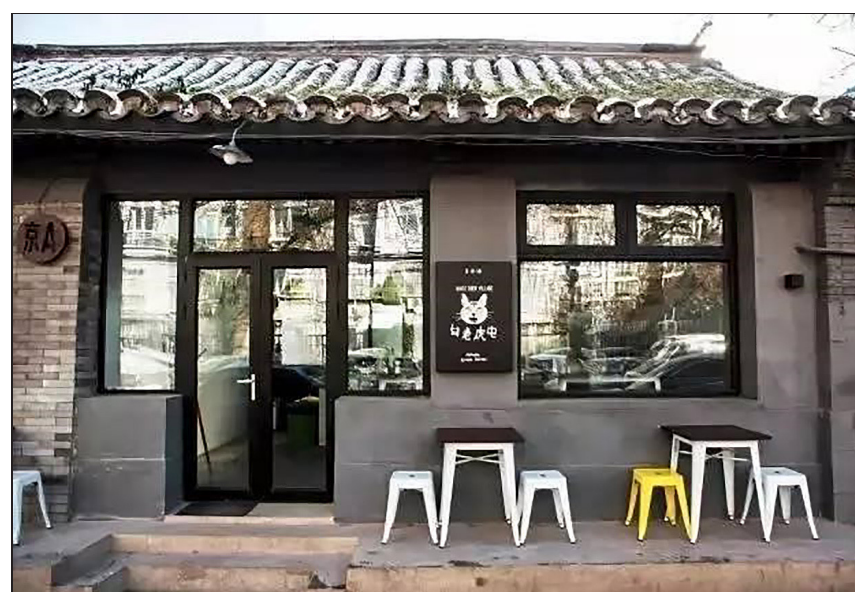

Figure 5: A neighborhood restaurant at Xiang'er Hutong No. 84 before renovation. Photo by MEI Shanshan, published on June 3, 2017 on http:// wx.imspender.com/articles/12zhang-hu-tong-zheng-zhi-qian. Accessed on September 16, 2017.

laid out in the thirteenth century, local residents have altered them based on changing social context and personal needs. Meanwhile, new social relations among residents emerged from, as well as were shaped and supported by, this evolving built environment. In other words, evolving dwelling types, living styles, and social relations inside hutongs continuously endow new meanings to this built environment. ${ }^{19}$ Therefore, the local execution of the Plan not only results in changing the appearance of hutongs, but also erases the history and memories embedded in the urban space, breaks down the social relations among local residents, and alters the meaning of the built environment. Using Premier Minister's words to summarize such a change, these restored and improved hutongs become "dead [spaces] without vitality."

\section{UNDERLYING AGENDA}

Although claiming to be an urban renewal movement, the Plan has two major underlying agendas, judging from its consequences. The first is to further eliminate non-permanent residents in Beijing and to control population mobility. Between 1998 and 2015, the population of Beijing increased by 74 percent, while the population of non-permanent residents quintupled, making up 37.9 percent of the overall population in 2015. ${ }^{20}$ Considering this a serious issue, the Beijing municipal government announced five measures to control population in July 2014, three of which targeted non-permanent residents. ${ }^{21}$ As a result, the number of nonpermanent residents decreased almost 2 percent, or by 151,000 people, between 2015 and 2016. ${ }^{22}$ However, this is not nearly enough. According to Beijing's Thirteenth FiveYear-Plan released in December 2015, 2,000,000 people must be dispersed from the six urban districts of Beijing, most of them non-permanent residents. ${ }^{23}$ Specifically, this plan proposes to use economic, legal and administrative measures to control population, such as to eliminate "low-end 
businesses" and control rental and housing markets. ${ }^{24}$ Thus, the local implementation of the Plan will provide an effective way to control non-permanent populations using both economic and legal methods. Without storefronts, these "low-end" small businesses will close down, forcing business owners who are non-permanent residents to leave; without doors or windows, rooms can no longer be rented to nonpermanent residents, forcing them to move out of the city. Although there are no official data yet on how many nonpermanent residents have left since the enactment of the Plan in April 2017, it is estimated that over 200,000 people will leave Beijing by the end of 2017 alone, due to the elimination of 16,000 small businesses through the sealing of doors and windows. ${ }^{25}$

The second underlying agenda of the Plan is part of a larger scheme that has been the focus of the Chinese government for years: to control social activities and relations. As the government has successfully surveilled the general public by monitoring information exchanged over the internet, the execution of the Plan will similarly restrain interpersonal relations at the local level by reconstructing places. Place, as the context for such relations, is not only a physical production, but also a political and social construction that represents locality and power relations. ${ }^{26}$ Therefore, as a form of representation, place is often manipulated and reconstructed by governments with specific agendas. In this case, the historic city center, a place identified by both the built environment and the social relations of the 99 percent, is being restructured to erase its local identity. At the same time, a new place is being produced to form the image of the modern and ahistorical capital of China as defined in the Master Plan: a place represented by the ideas of regularity, singularity and segregation. To achieve this goal, social interactions among the remaining residents of Beijing are restrained and controlled and their ownership of the architecture of the 99 percent is deprived.

\section{CONCLUSION}

Based on the original thirteenth century master plan, the urban fabric of the historic center of Beijing has continually evolved in the past 800 years. Although many hutongs retain their original settings and scales, the characteristics of urban lives within these hutongs have changed drastically as the result of increasing and diversified population that affect social activities and relations among residents. Meanwhile, the appearance of hutongs also changed from continuous solid walls occasionally interrupted by gates to collaged and dynamic street edges composed by store fronts of various styles.

As one of the largest cities in the world, Beijing encounters many urban issues as the result of rapid population inflation. In an effort to fundamentally solve these urban issues through redefining the urbanscape, functionality and population of the capital of China, the "Beijing Master Plan 2016-2030" was released in March 2017. To support this master plan, an urban renewal plan was enacted on April 1, 2017, which sets up specific approaches to eliminate ten urban issues. However, the local implementation of this Plan has focused primarily on sealing doors and windows within hutongs, which had led to homes and small businesses for years or decades. As a result, not only have the lives of local residents been greatly influenced, many non-permanent residents have been forced to relocate to other cities.

The embedded notion that supports the Plan and its local implementation is the negation of human factors that shape the built environment. Specifically, it denies local people's role in redefining their residential spaces-the architecture of the 99 percent-and endowing meanings to neighboring places. Therefore, simply restoring hutongs to their historical appearance not only erases histories and memories embedded in these vernacular buildings, but also discards the meanings of the built environment by breaking down the social activities and relations that are supported by the architecture of the 99 percent. More importantly, while using the improvement and restoration of the historic built environment as a camouflage, the Beijing municipal government is, in fact, instilling two underlying agendas: 1) it eliminates non-permanent residents and controls populating mobility through economic and legal measures; 2) it imposes another form of mass surveillance on social activities and relations by reconstructing place at the local level. In both cases, the architecture of the 99 percent is heavily charged with political, economic and social meanings. It not only provides spaces for many non-permanent residents to live and work, but also forms the physical and social context for interpersonal relations at the local level. By taking over ownership of the architecture of the 99 percent, the Beijing municipal government aims to create a new image of the capital of China that is not only ahistorical, but also represented by the ideas of regularity, singularity and segregation.

\section{ENDNOTES}

1 "The Action Plan to Renovate and Improve the Backstreets and Alleyways of the Center of the Capital City in Three Years (2017-2019) (首都核心区背街小巷 环境整治提升三年 (2017-2019年) 行动方案)," Beijing Civilization Web, April 1, 2017, accessed on August 8, 2017, http://www.bjwmb.gov.cn/xxgk/xgzl/ggl/ t20170410_819373.htm.

2 Xinian Fu, Ancient Chinese Urban Planning, Building Complex Layout and Building Design Methods (中国古代城市规划、建筑群布局及建筑设计方法研 究), Vol. 1 \& 2 (Beijing: China Architecture \& Building Press, 2001).

3 Yuchun Zhao, Traditional Construction Techniques of Beijing Courtyard House ( 北京四合院传统营造技艺) (Hefei, China: Anhui Science and Technology Press, 2013).

4 Yun Chen, Memoirs of life in China (中国生活记忆) (Beijing: China Light Industry Press, 2014): 60-61.

5 During the Cultural Revolution (1966-1976), many young people, following the communist propaganda, left the city to work in rural China.

6 “The First Privately Owned Restaurant in China (中国第一家餐饮个体户)," Sohu News, November 17, 2008, accessed on September 5, 2017, http://news.sohu. com/20081117/n260690391.shtml.

7 Zhenwu Zhai, "The Current Situation, Issues and Measurement of Chinese Population Migration (中国人口迁移的现状、问题与对策)," China Europe 
Forum, accessed on September 11, 2017. https://www.china-europa-forum. net/bdfdoc-998_zh.html.

8 According to the Beijing Municipal Bureau of Statistics, as cited in "The Number of Migrants in Beijing Decreased the First Time in 18 Years Last year: Tipping Point is Coming? (去年北京常住外来人口18年来首次减少 拐点来了?)," 163 News, February 26, 2017, accessed on September 11, 2017, http://news.163. com/17/0226/21/CE7UTR5I0001899N.html.

9 Ruoyu Yang, "The Living Situation, Assimilation Condition and Management Measurement for Migrant Population in Large Chinese Cities: Using Chongwen District in Beijing as a Case Study (中国大城市流动人口的生存现状、融入情 况与治理对策研究: 以北京崇文区为例)," Urbanological Studies, no. 1 (2015): 388-394.

10 Steven Lee Myers, "A Cleanup of 'Holes in the Wall' in China's Capital," NY Times, July 18, 2017, https://cn.nytimes.com/china/20170718/beijing-chinareconstruction-hutong/dual/, accessed on August 8, 2017.

11 Scott Doyle, Alexia Kelly-Schwartz, Marc Schlossberg \& Jean Stockard, "Active Community Environments and Health: The Relationship of Walkable and Safe Communities to Individual Health," Journal of the American Planning Association 72, no. 1 (2006): 19-31.

12 “'Beijing Master Plan 2016-2030’ Seeks Public Opinions (“北京城市总体规 划 (2016年-2030年)'编制进入征求公众意见阶段)," Xinhua News, March 28, 2017 , accessed on September 13, 2017, http://news.xinhuanet.com/local/201703/28/c_1120712019.htm.

13 The Central Committee of the Communist Party of China and the State Council Decided to Set Xiong'an, Hebei Province as the New District (中共中央、国务院 决定设立河北雄安新区),"Xinhua News, April 1, 2017, accessed on September 13, 2017, http://news.xinhuanet.com/politics/2017-04/01/c_1120741571.htm.

14 "The Action Plan to Renovate and Improve the Backstreets and Alleyways of the Center of the Capital City in Three Years (2017-2019)" Beijing Civilization Web, April 1, 2017.

15 "The Announcement to Lvmicang Alley regarding the Environmental Improvement of 'Hundred-Backstreet-Thousand-Alleyway' (关于绿米仓胡同 ‘ 百街千巷' 环境治理告知书)," Jianguomen Neighborhood Office, April 20, 2017. A photograph of this announcement was provided by Wenping Zhao, a local resident.

16 Wenping Zhao (local resident) in discussion with the author, April 27, 2017.

17 “Promote 'Internet + E-Commerce,' Li Keqiang Requires to Break Four Bottlenecks (推进 “互联网+流通” 李克强要求破除四大 “瓶颈” ), ” Government Net, April 8, 2016, accessed on September 16, 2017, http://www. gov.cn/xinwen/2016-04/08/content_5062517.htm.

18 Colin Rowe and Fred Koetter, Collage City (Cambridge, MA: MIT Press, 1978).

19 Amos Rapoport, The Meaning of the Built Environment: A Nonverbal Communication Approach (Beverly Hills: Sage Publications, 1982).

20 According to the Beijing Municipal Bureau of Statistics, as cited in "The Number of Migrants in Beijing Decreased the First Time in 18 Years Last year: Tipping Point is Coming?" 163 News, February 26, 2017, http://news.163. com/17/0226/21/CE7UTR5I0001899N.html.

21 “Five Important Measures in Controlling the Population of Beijing (控制北京人 口五大措施)," Beijing Government Net, July 10, 2014, http://zhengwu.beijing. gov.cn/zwzt/jkbjxfit/xcyd/IIxc/t1360860.htm, accessed on September 10, 2017.

22 According to the Beijing Municipal Bureau of Statistics, as cited in "The Number of Migrants in Beijing Decreased the First Time in 18 Years Last year: Tipping Point is Coming?" 163 News, February 26, 2017, http://news.163. com/17/0226/21/CE7UTR5I0001899N.html.

23 "2,000,000 People will be dispersed from the Six Urban Districts of Beijing in Five years; is Your Home Included? (5年内，城六区疏散200万人，有你家么?)," Yidu, January 26, 2016, https://read01.com/E46DR.html\#.Wb9IErKGOM8, accessed on September 17, 2017. Beijing has six urban districts and 10 suburban districts. Two of the six urban districts are the historic city.

24 “Beijing Municipal Government's Recomme ndations on Enacting Beijing's Thirteenth Five Year Plan on Civilian Economy and Social Development (北京 市委关于制定北京市国民经济和社会发展第十三个五年规划的建议), " Beijing Government Net, December 8, 2015, http://zhengwu.beijing.gov.cn/gzdt/gggs/ t1413440.htm, accessed on September 17, 2017.

25 The estimate is based on a survey, which states that over 2,000 non-permanent residents moved out of one street as the result of losing 136 small businesses. "How Many People Can be Dispersed from Beijing through Restoring 'Brake-Walls-Open-Holes' and Sealing Small Businesses? (整治 '开墙打洞' 封 堵小门店, 能为北京疏解多少人口?)," Caijing Magazine Online, May 15, 2017, http://yuanchuang.caijing.com.cn/2017/0515/4271908.shtml, accessed on September 17, 2017
26 Arjun Appadurai, "The Production of Locality." In Counterworks: Managing the Diversity of Knowledge, ed. Richard Fardon and Association of Social Anthropologists of the Commonwealth. Conference (New York: Routledge, 1995), 204-25. Dolores Hayden, The Power of Place: Urban Landscapes as Public History (Cambridge, MA: MIT Press, 1995). 